\title{
Correction to: Cancer associated fibroblasts (CAFs) are activated in cutaneous basal cell carcinoma and in the peritumoural skin
}

Silje Haukali Omland ${ }^{1 *}$, Erika Elgstrand Wettergren ${ }^{1}$, Sarah Mollerup ${ }^{2}$, Maria Asplund², Tobias Mourier², Anders Johannes Hansen ${ }^{2}$ and Robert Gniadecki ${ }^{3}$

\section{Correction}

After publication of the original article [1] it was identified that order of the author list had been presented incorrectly. The author Robert Gniadecki's surname was also incorrect in the original article.

The original article has been updated and the updated author list is also presented in this Correction.

\footnotetext{
Author details

'Department of Dermato-Venerology, Bispebjerg University Hospital, Bispebjerg Bakke 23, 2400 Copenhagen, Nordvest, Denmark. ${ }^{2}$ Centre for GeoGenetics, Natural History Museum, University of Copenhagen, Copenhagen, Denmark. ${ }^{3}$ Division of Dermatology, Faculty of Medicine, University of Alberta, Edmonton, Canada.
}

Received: 3 January 2018 Accepted: 3 January 2018 Published online: 30 January 2018

\section{Reference}

1. Omland SH, Wettergren EE, Mollerup S, Asplund M, Mourier T, Hansen AJ,

Gniadecki R. Cancer associated fibroblasts (CAFs) are activated in cutaneous basal cell carcinoma and in the peritumoural skin. BMC Cancer. 2017;17:675. doi: https://doi.org/10.1186/s12885-017-3663-0.

\footnotetext{
* Correspondence: Silje.haukali.omland.01@regionh.dk

1 Department of Dermato-Venerology, Bispebjerg University Hospital,

Bispebjerg Bakke 23, 2400 Copenhagen, Nordvest, Denmark

Full list of author information is available at the end of the article
} 